Article

\title{
The Effect of Serum 25-Hydroxyvitamin D Concentrations on Elevated Serum C-Reactive Protein Concentrations in Normal Weight, Overweight and Obese Participants of a Preventive Health Program
}

\author{
Silmara S. B. S. Mastroeni ${ }^{1,2}$, Lalani L. Munasinghe ${ }^{2}$, Truong-Minh Pham ${ }^{2}$, Sarah A. Loehr ${ }^{2}$, \\ John Paul Ekwaru ${ }^{2}$, Marco F. Mastroeni ${ }^{2,3}$ and Paul J. Veugelers ${ }^{2, *}$ \\ 1 Department of Physical Education, University of Joinville Region, Rua Paulo Malschitzki, No. 10, \\ Joinville 89.219-710, Brazil; silmara.mastroeni@univille.br \\ 2 Population Health Intervention Research Unit, School of Public Health, University of Alberta, \\ 3-50 University Terrace, 8303-112 St., Edmonton, AB T6G 2T4, Canada; lalani.m@ualberta.ca (L.L.M.); \\ truongminh.pham@ualberta.ca (T.-M.P.); Sarah.Loehr@ualberta.ca (S.A.L.); ekwaru@ualberta.ca (J.P.E.), \\ marco.mastroeni@univille.br (M.F.M.) \\ 3 Post-graduation Program in Health and Environment, University of Joinville Region, Rua Paulo Malschitzki, \\ No. 10, Joinville 89.219-710, Brazil \\ * Correspondence: paul.veugelers@ualberta.ca; Tel.: +1-780-492-9954; Fax: +1-780-492-0364
}

Received: 23 August 2016; Accepted: 1 November 2016; Published: 4 November 2016

\begin{abstract}
The hypothesized effect of vitamin D on C-reactive protein (CRP) has received substantial attention as a potential means to alleviate the risk for cardiovascular disease. However, observational studies have been inconsistent in their reporting of associations between serum 25-hydroxyvitamin $\mathrm{D}(25(\mathrm{OH}) \mathrm{D})$ and CRP concentrations, and trials and meta analyses have been inconsistent in their conclusions regarding the effect of vitamin D supplementation on CRP concentrations. These supplementation trials were mostly conducted among patients with more or less inflammatory complications and did not consider potential distinctive effects by weight status. To further our understanding of the potential influences of vitamin D on CRP, we analyzed longitudinal observations of 6755 participants of a preventative health program. On average, serum $25(\mathrm{OH}) \mathrm{D}$ concentrations increased from 88.3 to $121.0 \mathrm{nmol} / \mathrm{L}$ and those of CRP decreased from 1.7 to $1.6 \mathrm{mg} / \mathrm{L}$ between baseline and follow up. Relative to obese participants without temporal increases in $25(\mathrm{OH}) \mathrm{D}$, those who showed improvements of $<25,25-50,50-75$, and more than $75 \mathrm{nmol} / \mathrm{L}$ at follow up were 0.57 (95\% confidence interval: $0.37-0.88), 0.54$ (0.34-0.85), 0.49 (0.30-0.80), and $0.48(0.29-0.78)$ times as likely to have elevated CRP concentrations $(\geq 1 \mathrm{mg} / \mathrm{L})$, respectively. These associations were less pronounced and not statistically significant for normal weight and overweight participants. Herewith, the findings suggest that promotion of adequate serum $25(\mathrm{OH}) \mathrm{D}$ concentrations among obese individuals along with healthy lifestyles may alleviate the public health burden associated with cardiovascular disease.
\end{abstract}

Keywords: serum 25-hydroxyvitamin D; vitamin D; C-reactive protein; inflammation; obesity; cardiovascular disease

\section{Introduction}

C-reactive protein (CRP) is a novel risk factor for cardiovascular disease (CVD) [1-3]. It is a positive acute phase protein produced by hepatocytes in low quantities under normal conditions and in higher quantities in response to acute phase stimuli such as inflammation, infections, allergies and trauma $[1,3,4]$. As a chronic low-grade inflammatory state and an established risk factor for CVD, excess body weight increases serum CRP concentrations [2,5-7]. Reducing serum CRP concentrations 
has therefore been considered as an approach to decrease the risk for CVD [8,9], particularly among obese individuals.

Vitamin D is synthesized in the skin when exposed to sunlight, and can be ingested through the diet and supplementation [10]. Where the role of vitamin D in sustaining calcium homeostasis and bone health is well established [10,11], vitamin D has also been suggested to have other health benefits such as the prevention of CVD $[2,3,8,12]$. CRP may be involved in one or more of the various pathways through which vitamin D moderates the risk for CVD. The potential importance of vitamin D for serum CRP concentrations has received great attention in recent years. Observational studies have reported, though not consistently, associations between serum 25-hydroxyvitamin D (25(OH)D) and CRP concentrations [13-15]. Randomized controlled trials (RCT) [16-22] have produced inconsistent findings with respect to the effect of vitamin D supplementation regimens on serum CRP concentrations. A meta-analysis focusing on supplementation trials among overweight and obese individuals concluded the absence of a significant influence of vitamin D supplementation on serum CRP concentrations [23]. A meta-analysis of supplementation trials published since 2010 concluded the presence of such an influence [24], suggesting the influence of vitamin D on CRP may differ by body weight. In addition, because the participants of most of the RCTs were patients with more or less inflammatory complications, their results are difficult to generalize to the general population [24], prompting the need for supplementation studies in community samples. Furthermore, because RCTs quantify the influence of vitamin D supplementation regimens on changes in serum CRP concentrations, they do not provide a good understanding of how temporal changes in serum $25(\mathrm{OH}) \mathrm{D}$ concentrations affect the risk for reaching adverse CRP concentrations. The latter risk estimates may be more informative for clinical and public health decision making as they also consider the influence of sun exposure and diet. Therefore, the objective of this study was to examine whether temporal increases in serum $25(\mathrm{OH}) \mathrm{D}$ concentrations are paralleled by a reduction in the risk for reaching adverse CRP concentrations in a community sample. This objective was also addressed separately for normal weight, overweight and obese subjects.

\section{Methods}

\subsection{Study Design and Participants}

The data for the present study were obtained from the Pure North S'Energy Foundation (PN), a not-for-profit organization, in Calgary, Alberta, Canada that offers a preventative health program to community volunteers. Details of the program have been previous publish elsewhere $[25,26]$ and further information can be found on the PN website (http://purenorth.ca/pure-north-program/). In brief, established in 2007, this program employs health professional to offer lifestyle counseling to volunteer participants. At enrollment, all participants complete a demographic and lifestyle questionnaire, and provide information regarding their medical history and medication and supplement use. Blood pressure and anthropometric measurements are taken by trained professionals, and blood is drawn for the assessment of several biomarkers including serum $25(\mathrm{OH}) \mathrm{D}$ and high sensitive CRP (hs-CRP). The information collected is used to guide lifestyle counseling. Vitamin D supplementation is encouraged given Canada's Northern latitude, limited sunlight and inadequate cutaneous synthesis of vitamin D. Follow-up visits, which include both assessments and counseling, are scheduled annually. Data collected from October 2007 through April 2014 were used for the current analyses. Participants signed and granted written informed consent for the use of their relevant information for research purposes. All data were anonymized by PN prior to it being transferred to the University of Alberta for data analyses. Ethical approval was obtained from the Human Research Ethics Board at the University of Alberta (Pro00028578).

Figure 1 provides a flow chart of the participants in the PN program included in the present analysis. A total of 7579 adult participants had at least two measures of serum 25(OH)D concentrations and serum CRP concentrations, one at baseline and one or more follow-up visits. The focus of the 
present study is chronic inflammation and CVD risk; therefore, observations were excluded from the analyses if serum CRP concentrations were in excess of $10 \mathrm{mg} / \mathrm{L}(n=606)$ due to the possibility that such a high concentration was caused by acute infections or inflammations rather than chronic inflammation [27], or if white blood cell concentrations were in excess of 10,000 cells $/ \mu \mathrm{L}(n=139)$ due to the possibility of an acute infection. Observations were also excluded if information on weight or height was missing $(n=79)$. The final analysis included data from 6755 participants contributing to 6755 baseline visits and 10,383 follow-up visits (Figure 1).

24,677 individuals enrolled the program between

October 2007 and April 2014 and consented their information be used for research

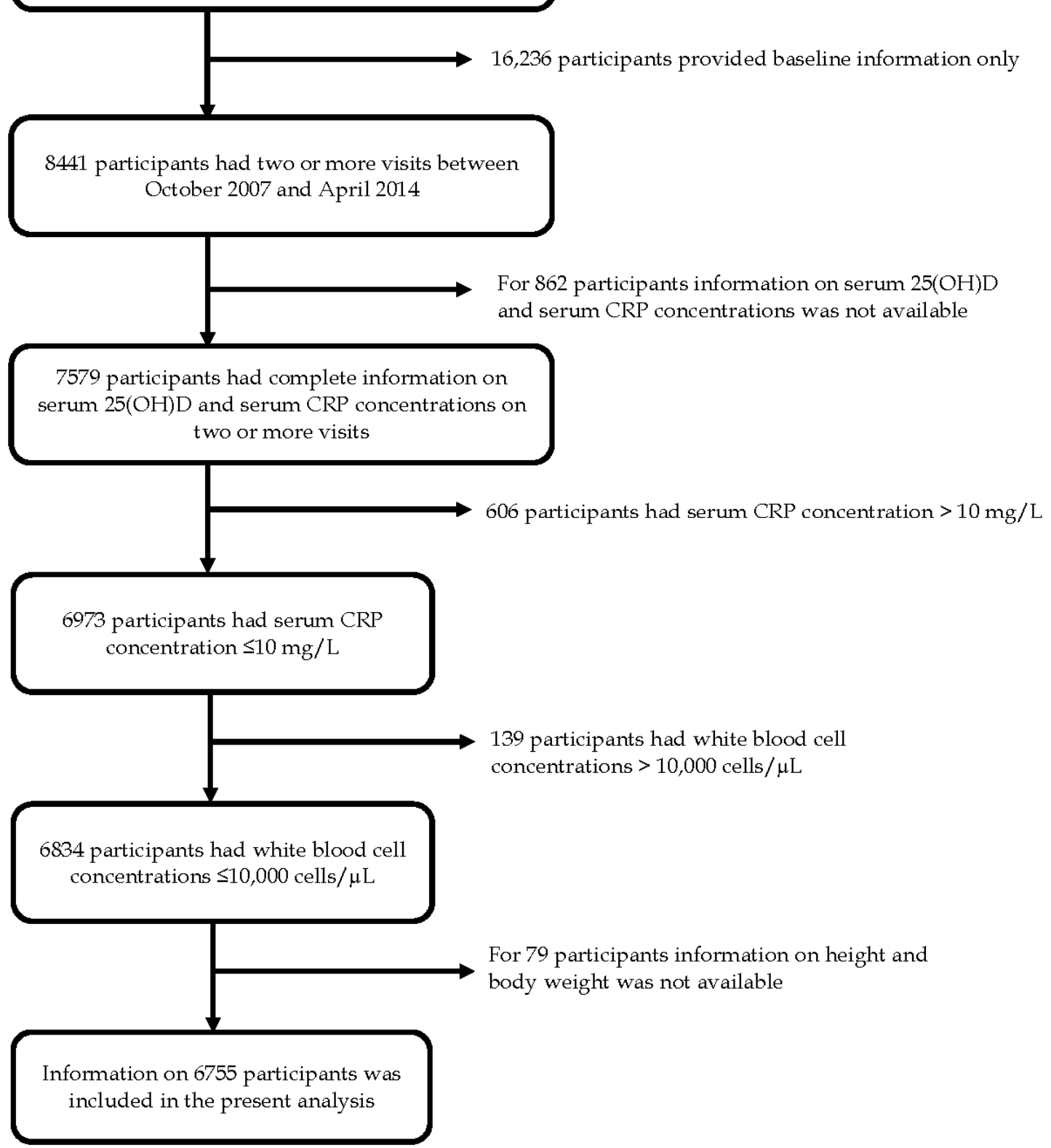

Figure 1. Flow chart of adult participants of the Pure North preventive health program. 


\subsection{Serum CRP Concentrations}

High-sensitive CRP, which is sensitive to the detection of small changes at low serum CRP concentrations (below $10 \mathrm{mg} / \mathrm{L}$ ) [28], was determined using an immunoturbidimetric principle on an automated analyzer with the inter-assay CV of $2.5 \%$. Serum CRP concentrations were categorized into three groups as "low CVD-risk ( $<1 \mathrm{mg} / \mathrm{L})$ ", "average CVD-risk ( 1 to $<3 \mathrm{mg} / \mathrm{L})$ " and "high CVD-risk $(\geq 3 \mathrm{mg} / \mathrm{L})$ " as per established criteria [27] though alternative categorizations have also been published [29].

\subsection{Serum $25(\mathrm{OH}) \mathrm{D}$ Concentrations}

Serum 25(OH)D concentrations were determined using DiaSorin ${ }^{\circledR}$ Liason chemiluminescent immunoassay with an inter-assay coefficient of variation $(\mathrm{CV})$ of $11 \%$. Baseline $25(\mathrm{OH}) \mathrm{D}$ were categorized into five groups ( $<50,50$ to $<75,75$ to $<100,100$ to $<125$ and $\geq 125 \mathrm{nmol} / \mathrm{L}$ ) based on their distribution against serum CRP. The change in $25(\mathrm{OH}) \mathrm{D}$ was calculated by subtracting the baseline concentration from the follow-up concentration. Changes were categorized into five groups (no improvement, increased by $<25$, increased by 25 to $<50$, increased by 50 to $<75$ and increased by $\geq 75 \mathrm{nmol} / \mathrm{L})$.

\subsection{Body Weight Status}

To determine body weight status, body mass index (BMI) was calculated for each participant as weight in $\mathrm{kg} / \mathrm{height}^{2}\left(\mathrm{~kg} / \mathrm{m}^{2}\right)$; BMI was then categorized as "underweight $\left(<18.5 \mathrm{~kg} / \mathrm{m}^{2}\right)$ ", "normal weight $\left(18.5 \text { to }<25 \mathrm{~kg} / \mathrm{m}^{2}\right)^{\prime}$, "overweight $\left(25 \text { to }<30 \mathrm{~kg} / \mathrm{m}^{2}\right)^{\text {", }}$, and "obesity $\left(\geq 30 \mathrm{~kg} / \mathrm{m}^{2}\right)$ " [30]. Due to low prevalence of underweight participants, underweight and normal weight individuals were combined into one group in the regression analysis.

\subsection{Potential Confounding Variables}

Low-density lipoprotein (LDL) cholesterol, age, gender, blood pressure, smoking, alcohol consumption, and physical activity have all been associated with CVD and were considered as potential confounding variables in the present study. Automated Cobas ${ }^{\circledR} 8000$ Modular Analyzer Series was used to measure concentrations of serum triglycerides (inter-assay $\mathrm{CV}=2 \%$ ), total cholesterol (inter-assay CV $=1.5 \%$ ), and high-density lipoprotein ( $\mathrm{HDL}$; inter-assay $\mathrm{CV}=2 \%$ ). LDL concentrations were calculated using the formula, "LDL = Total Cholesterol - HDL - (Triglycerides/2.2)", and categorized as "Normal $(<2.6 \mathrm{mmol} / \mathrm{L})$ " and "Elevated $(\geq 2.6 \mathrm{mmol} / \mathrm{L})$ ". Blood pressure status was defined as "Normal" if systolic and diastolic pressures were $<140 / 90 \mathrm{mmHg}$, and as "Elevated" if they were $\geq 140 / 90 \mathrm{mmHg}$ or if the participant was using an anti-hypertensive medication. Information on age, gender, smoking status ("never smoker", "past smoker", and "current smoker"), alcohol consumption and physical activities for a typical week (light, moderate and vigorous activities) was ascertained from the self-reported lifestyle questionnaire. The alcohol consumption status was defined as "non-drinker" for those who reported drinking $<2$ glasses per week and "drinker" for those who drank $\geq 2$ glasses per week. Physical activity levels were determined by estimating the metabolic equivalent of task (MET) per week for each physical activity recorded by participants on their questionnaires. MET values were then multiplied by the time participants spent performing those activities per week (MET * hours per week), and the total for each week was categorized as "low ( $<10$ MET hours/week)", "moderate (10 to $<20$ MET hours/week)" and "high ( $\geq 20$ MET hours/week)". MET hours per week at baseline were subtracted from the MET hours per week at the follow-up visit to determine change in physical activity. Change in physical activity was categorized as "Negative change" if MET hours per week were greater at baseline than follow-up, "No change" if MET hours per week remained constant and "Positive change" MET hours per week were greater at follow-up than baseline. 


\subsection{Statistical Analyses}

Descriptive statistics were presented for both baseline visits and the last follow-up visits. Serum CRP concentrations of $<1 \mathrm{mg} / \mathrm{L}$ representing "low CVD risk" were contrasted with serum CRP concentration of $\geq 1 \mathrm{mg} / \mathrm{L}$ representing "elevated CRP" that combines the categories "average CVD-risk" and "high CVD-risk" associated with elevated CRP [4]. Multiple logistic regression analyses with mixed effects to accommodate the repeated measures of participants were used to quantify the associations of $25(\mathrm{OH}) \mathrm{D}$ at baseline and changes in $25(\mathrm{OH}) \mathrm{D}$ during follow-up with elevated CRP at follow-up. These regression analyses were adjusted for elevated CRP at baseline, baseline LDL-cholesterol, age, gender, baseline blood pressure, baseline smoking status, baseline alcohol consumption status, baseline physical activity level and change in physical activity level. These associations were quantified separately for normal weight, overweight and obese individuals. Missing observations for confounding variables were treated as separate covariate categories and presented as "Missing". All statistical analyses were performed using Stata, version 14.0 (Stata Corp, College Station, TX, USA) with statistical significance at 0.05 .

\section{Results}

Participant characteristics at baseline and at the last follow-up visit are presented in Table 1. Mean serum 25(OH)D concentrations increased from $88.3 \mathrm{nmol} / \mathrm{L}$ at baseline to $121.0 \mathrm{nmol} / \mathrm{L}$ at the last follow-up visit, with a concurrent decrease in mean CRP from $1.7 \mathrm{mg} / \mathrm{L}$ at baseline to $1.6 \mathrm{mg} / \mathrm{L}$ at the last follow-up visit. The prevalence of elevated CRP concentrations (serum CRP concentrations of 1 $\mathrm{mg} / \mathrm{L}$ or more) decreased from $53.0 \%$ to $48.8 \%$. The median time between baseline and the last follow up visit was 1.1 year.

Table 1. Baseline and follow-up characteristics of 6755 study participants.

\begin{tabular}{|c|c|c|}
\hline Characteristic & Baseline & Last Follow-up Visit \\
\hline \multicolumn{3}{|l|}{ Serum $25(\mathrm{OH}) \mathrm{D}, \mathrm{nmol} / \mathrm{L}$} \\
\hline Mean (SD) & $88.3(42.2)$ & $121.0(46.2)$ \\
\hline Median (IQR) & $81.6(60.5-108.0)$ & $115.0(88.60-147.0)$ \\
\hline \multicolumn{3}{|l|}{ Serum C-reactive protein, $\mathrm{mg} / \mathrm{L}$} \\
\hline Mean (SD) & $1.7(1.8)$ & $1.6(1.8)$ \\
\hline Median (IQR) & $1.0(0.5-2.2)$ & $0.9(0.4-2.1)$ \\
\hline \multicolumn{3}{|l|}{ Elevated C-reactive protein, $\%$} \\
\hline Low-risk $(<1 \mathrm{mg} / \mathrm{L})$ & 47.0 & 51.2 \\
\hline Average risk (1-2.99 mg/L) & 35.6 & 32.6 \\
\hline High risk $(\geq 3 \mathrm{mg} / \mathrm{L})$ & 17.4 & 16.2 \\
\hline \multicolumn{3}{|l|}{ Gender (\%) } \\
\hline Female & 52.0 & 52.0 \\
\hline Male & 48.0 & 48.0 \\
\hline \multicolumn{3}{|l|}{ Age } \\
\hline Mean (SD) & $50.9(15.2)$ & $52.4(15.0)$ \\
\hline \multicolumn{3}{|l|}{ Body weight status, $\%$} \\
\hline Under weight & 1.0 & 1.0 \\
\hline Normal weight & 34.2 & 34.3 \\
\hline Over weight & 38.2 & 37.7 \\
\hline Obesity & 26.6 & 27.0 \\
\hline \multicolumn{3}{|l|}{ Blood pressure, $\%$ * } \\
\hline Normal $(<140 / 90 \mathrm{mmHg})$ & 58.9 & 53.2 \\
\hline Elevated ( $\geq 140 / 90 \mathrm{mmHg}$ or anti-hypertensive medication use) & 36.2 & 33.6 \\
\hline Missing & 4.9 & 13.2 \\
\hline \multicolumn{3}{|l|}{ Serum LDL-cholesterol, \% ${ }^{\dagger}$} \\
\hline Normal $(<2.6 \mathrm{mmol} / \mathrm{L})$ & 34.3 & 30.0 \\
\hline Elevated $(\geq 2.6 \mathrm{mmol} / \mathrm{L})$ & 61.7 & 67.3 \\
\hline Missing & 4.0 & 2.7 \\
\hline
\end{tabular}


Table 1. Cont.

\begin{tabular}{lcc}
\hline Characteristic & Baseline & Last Follow-up Visit \\
\hline Smoking status, \% & & 30.2 \\
Never smoker & 41.5 & 15.6 \\
Ex-smoker & 21.6 & 6.6 \\
Current smoker & 8.7 & 47.6 \\
Missing & 28.2 & 26.6 \\
Alcohol consumption status, \% & & 41.6 \\
Non-drinker & 25.3 & 31.8 \\
Drinker & 42.1 & 28.3 \\
Missing & 32.6 & 21.5 \\
Physical activity level, \% & & 21.0 \\
Low & 28.3 & 29.2 \\
Moderate & 21.5 & 74.2 \\
High & 21.0 & 9.6 \\
Missing & 29.2 & 16.2 \\
Use of vitamin D-containing supplements, \% & & $6000(4000-9000)$ \\
Yes & 47.4 & 35.7 \\
No & 16.9 & \\
Missing & $3000(2000-5000)$ & 6 \\
Vitamin D dose of the supplements, Median (IQR) IU/day & & \\
\hline
\end{tabular}

Abbreviations: 25(OH)D, 25-hydroxyvitamin D; LDL-cholesterol, low-density lipoprotein cholesterol; SD, standard deviation; IQR, interquartile range; * Blood pressure status was defined based on blood pressure $\geq 140 / 90 \mathrm{~mm} \mathrm{Hg}$, or a self-report of taking antihypertensive medications as elevated; ${ }^{\dagger}$ Elevated LDL-cholesterol was defined as LDL-cholesterol concentration $\geq 2.6 \mathrm{mmol} / \mathrm{L}$.

Table 2 depicts the results of the longitudinal analysis of the risk for elevated CRP concentrations at follow-up. Baseline measures including lower 25(OH)D, elevated CRP, elevated LDL-cholesterol, older age, female gender, being overweight or obese, and being a current smoker were associated with an increased risk for elevated CRP at follow-up. Baseline physical activity levels and increases in physical activity were inversely associated with the risk for elevated CRP.

Table 2. Risk for elevated C-reactive protein concentration ( $\geq 1 \mathrm{mg} / \mathrm{L})$ at follow-up among 6755 participants with a total of 10,383 follow up visits.

\begin{tabular}{|c|c|c|c|c|c|}
\hline & \multirow{2}{*}{ \# Visits } & Univariable model $\S$ & \multirow{2}{*}{$p$} & Multivariable model $\S$ & \multirow{2}{*}{$p$} \\
\hline & & OR $(95 \% \mathrm{CI})$ & & OR $(95 \%$ CI $)$ & \\
\hline \multicolumn{6}{|c|}{ Serum 25(OHD) at baseline, $\mathrm{nmol} / \mathrm{L}$} \\
\hline $50-<75$ & 2878 & $0.56(0.41,0.76)$ & $<0.01$ & $0.72(0.56,0.92)$ & 0.01 \\
\hline $75-<100$ & 2655 & $0.28(0.20,0.38)$ & $<0.01$ & $0.61(0.47,0.80)$ & $<0.01$ \\
\hline $100-<125$ & 1665 & $0.24(0.17,0.34)$ & $<0.01$ & $0.61(0.45,0.82)$ & $<0.01$ \\
\hline \multicolumn{6}{|c|}{ Change in serum $25(\mathrm{OH}) \mathrm{D}, \mathrm{nmol} / \mathrm{L}$} \\
\hline No improvement & 2032 & ref & & ref & \\
\hline Increase of $<25$ & 2370 & $1.38(1.09,1.76)$ & 0.01 & $0.92(0.74,1.15)$ & 0.46 \\
\hline Increase of $25-<50$ & 2415 & $1.23(0.97,1.57)$ & 0.09 & $0.84(0.77,1.05)$ & 0.13 \\
\hline Increase of $50-<75$ & 1670 & $1.37(1.05,1.78)$ & 0.02 & $0.88(0.68,1.13)$ & 0.31 \\
\hline Increase of $\geq 75$ & 1896 & $1.28(0.99,1.67)$ & 0.06 & $0.88(0.69,1.13)$ & 0.32 \\
\hline \multicolumn{6}{|c|}{ Serum LDL-cholesterol at baseline * } \\
\hline Normal & 3441 & ref & & ref & \\
\hline Elevated & 6511 & $2.31(1.87,2.85)$ & $<0.01$ & $1.29(1.09,1.53)$ & $<0.01$ \\
\hline Missing & 431 & $2.97(1.79,4.91)$ & $<0.01$ & $1.38(0.92,2.06)$ & 0.12 \\
\hline Age at baseline (per 10 years) & 10,383 & $1.34(1.25,1.43)$ & $<0.01$ & $1.13(1.06,1.19)$ & $<0.01$ \\
\hline
\end{tabular}


Table 2. Cont.

\begin{tabular}{|c|c|c|c|c|c|}
\hline & \multirow{2}{*}{ \# Visits } & Univariable model $\S$ & \multirow{2}{*}{$p$} & Multivariable model ${ }^{\S}$ & \multirow{2}{*}{$p$} \\
\hline & & OR $(95 \% \mathrm{CI})$ & & OR $(95 \% \mathrm{CI})$ & \\
\hline \multicolumn{6}{|l|}{ Gender } \\
\hline Female & 5188 & ref & & ref & \\
\hline Male & 5195 & $1.05(0.87,1.28)$ & 0.58 & $0.75(0.63,0.89)$ & $<0.01$ \\
\hline \multicolumn{6}{|l|}{ Body weight status at baseline } \\
\hline Underweight/normal weight & 3526 & ref & & ref & \\
\hline Overweight & 4028 & $4.88(3.88,6.14)$ & $<0.01$ & $2.17(1.79,2.63)$ & $<0.01$ \\
\hline Obesity & 2829 & $39.03(28.35,53.71)$ & $<0.01$ & $5.30(4.17,6.74)$ & $<0.01$ \\
\hline \multicolumn{6}{|l|}{ Blood pressure status at baseline ${ }^{\dagger}$} \\
\hline Normal & 5993 & ref & & ref & \\
\hline Elevated & 3752 & $3.83(3.09,4.76)$ & $<0.01$ & $1.15(0.97,1.37)$ & 0.12 \\
\hline Missing & 638 & $1.59(1.03,2.46)$ & 0.03 & $1.10(0.78,1.55)$ & 0.60 \\
\hline \multicolumn{6}{|l|}{ Smoking status at baseline } \\
\hline Never smoker & 3870 & ref & & ref & \\
\hline Past smoker & 1996 & $1.59(1.22,2.05)$ & $<0.01$ & $1.04(0.84,1.29)$ & 0.70 \\
\hline Current smoker & 743 & $1.87(1.29,2.70)$ & $<0.01$ & $1.70(1.25,1.31)$ & $<0.01$ \\
\hline Missing & 3774 & $1.65(1.31,2.08)$ & $<0.01$ & $0.91(0.62,1.32)$ & 0.62 \\
\hline \multicolumn{6}{|c|}{ Alcohol consumption status at baseline } \\
\hline Non-drinker & 2273 & ref & & ref & \\
\hline Drinker & 3966 & $0.66(0.52,0.84)$ & $<0.01$ & $0.99(0.81,1.21)$ & 0.91 \\
\hline Missing & 4144 & $1.28(1.00,1.65)$ & 0.05 & $1.22(0.96,1.54)$ & 0.10 \\
\hline \multicolumn{6}{|l|}{ Physical activity level at baseline } \\
\hline Low & 2637 & ref & & ref & \\
\hline Moderate & 1975 & $0.46(0.35,0.61)$ & $<0.01$ & $0.83(0.66,1.04)$ & 0.10 \\
\hline High & 1927 & $0.26(0.20,0.35)$ & $<0.01$ & $0.75(0.58,0.95)$ & 0.02 \\
\hline Missing & 3844 & $0.78(0.61,1.00)$ & 0.05 & $1.31(0.87,1.98)$ & 0.19 \\
\hline \multicolumn{6}{|l|}{ Change in physical activity level } \\
\hline Negative change & 1984 & ref & & ref & \\
\hline No change & 394 & $0.71(0.46,1.09)$ & 0.12 & $0.60(0.40,0.89)$ & 0.01 \\
\hline Positive change & 2464 & $0.75(0.59,0.96)$ & 0.02 & $0.67(0.54,0.83)$ & $<0.01$ \\
\hline Missing & 5541 & $0.98(0.79,1.23)$ & 0.87 & $0.81(0.64,1.03)$ & 0.08 \\
\hline
\end{tabular}

Abbreviations: OR, Odds Ratio; 95\% CI, 95\% Confidence Interval; 25(OH)D, 25-hydroxyvitamin D; CVD, cardiovascular disease; CRP, C-reactive protein; LDL-cholesterol, low-density lipoprotein cholesterol; SD, standard deviation; IQR, interquartile range; ${ }^{\S}$ Adjusted for all covariates in the table; ${ }^{*}$ Elevated LDL-cholesterol was defined as LDL-cholesterol concentration $\geq 2.6 \mathrm{mmol} / \mathrm{L} ;{ }^{\dagger}$ Blood pressure status was defined based on blood pressure $\geq 140 / 90 \mathrm{~mm} \mathrm{Hg}$, or a self-report of taking antihypertensive medications as "elevated".

Table 3 shows the associations of baseline 25(OH)D concentrations and temporal changes in 25(OH)D concentrations with the risk for elevated CRP concentrations at follow-up by body weight status adjusted for the same confounders as considered in the above analyses and listed in Table 2. For underweight and normal weight participants, neither baseline $25(\mathrm{OH}) \mathrm{D}$ concentrations nor changes in $25(\mathrm{OH}) \mathrm{D}$ concentrations were associated with the risk for elevated CRP at follow-up. Overweight participants with baseline 25(OH)D concentrations above $75 \mathrm{nmol} / \mathrm{L}$ had a lower risk of elevated CRP at follow-up relative to those with lower baseline 25(OH)D concentrations. For obese participants, both baseline $25(\mathrm{OH}) \mathrm{D}$ concentrations and changes in $25(\mathrm{OH}) \mathrm{D}$ concentrations were inversely associated with the risk for elevated CRP concentrations at follow-up (Table 3).

In the above analyses, we considered serum CRP concentration of $\geq 1 \mathrm{mg} / \mathrm{L}$ as "elevated CRP" to capture both average CVD-risk ( $\geq 1 \mathrm{mg} / \mathrm{L}$ and $<3 \mathrm{mg} / \mathrm{L}$ ) and high CVD-risk ( $\geq 3 \mathrm{mg} / \mathrm{L}$ ). A comparison considering serum CRP concentration of $\geq 3 \mathrm{mg} / \mathrm{L}$ as "elevated CRP" and $<3 \mathrm{mg} / \mathrm{L}$ as "not elevated" revealed similar findings in that the associations of baseline $25(\mathrm{OH}) \mathrm{D}$ concentrations and temporal changes in 25(OH)D concentrations with the risk for elevated CRP concentrations at follow-up were statistically significant for obese participants, but not for underweight and normal weight participants. These results are included in Supplementary Table S1. 
Table 3. Risk for elevated C-reactive protein concentration $(\geq 1 \mathrm{mg} / \mathrm{L})$ at follow-up by body weight status.

\begin{tabular}{|c|c|c|c|c|c|c|}
\hline & \multicolumn{2}{|c|}{$\begin{array}{c}\text { Underweight/Normal Weight } \S \\
\text { \# Follow up Visits }=3526\end{array}$} & \multicolumn{2}{|c|}{$\begin{array}{l}\text { Overweight and Not Obese } \\
\text { \# Follow up Visits }=4028\end{array}$} & \multicolumn{2}{|c|}{$\begin{array}{c}\text { Obese }^{\S} \\
\text { \# Follow up Visits }=2829\end{array}$} \\
\hline & OR $(95 \% \mathrm{CI})$ & $p$ & OR $(95 \% \mathrm{CI})$ & $p$ & OR $(95 \%$ CI $)$ & $p$ \\
\hline \multicolumn{7}{|c|}{ Serum $25(\mathrm{OHD})$ at baseline, $\mathrm{nmol} / \mathrm{L}$} \\
\hline$<50$ & ref & & ref & & ref & \\
\hline $50-<75$ & $0.71(0.42,1.19)$ & 0.19 & $0.82(0.57,1.20)$ & 0.31 & $0.59(0.38,0.92)$ & 0.02 \\
\hline $75-<100$ & $0.63(0.38,1.05)$ & 0.08 & $0.58(0.39,0.86)$ & 0.01 & $0.66(0.40,1.10)$ & 0.11 \\
\hline $100-<125$ & $0.67(0.39,1.16)$ & 0.15 & $0.62(0.39,0.96)$ & 0.03 & $0.51(0.27,0.96)$ & 0.04 \\
\hline$\geq 125$ & $0.64(0.36,1.14)$ & 0.13 & $0.69(0.43,1.13)$ & 0.14 & $0.35(0.17,0.73)$ & $<0.01$ \\
\hline \multicolumn{7}{|c|}{ Change in serum $25(\mathrm{OH}) \mathrm{D}, \mathrm{nmol} / \mathrm{L}$} \\
\hline No improvement & ref & & ref & & ref & \\
\hline Increase of $<25$ & $1.16(0.79,1.68)$ & 0.45 & $0.90(0.64,1.27)$ & 0.55 & $0.62(0.39,1.00)$ & 0.05 \\
\hline Increase of $25-<50$ & $1.12(0.76,1.67)$ & 0.56 & $0.79(0.55,1.12)$ & 0.18 & $0.58(0.35,0.96)$ & 0.03 \\
\hline Increase of $50-<75$ & $1.25(0.82,1.91)$ & 0.30 & $0.86(0.58,1.26)$ & 0.43 & $0.54(0.32,0.92)$ & 0.02 \\
\hline Increase of $\geq 75$ & $1.40(0.92,2.13)$ & 0.12 & $0.82(0.56,1.20)$ & 0.30 & $0.52(0.31,0.89)$ & 0.02 \\
\hline
\end{tabular}

Abbreviations: OR, Odds Ratio; 95\% CI, 95\% Confidence Interval; CVD, cardiovascular disease; CRP, C-reactive protein; LDL-cholesterol, low density lipoprotein cholesterol; $\$$ Adjusted for elevated CRP at baseline, LDL-cholesterol at baseline, age at baseline, gender, blood pressure status baseline, smoking status at baseline, alcohol consumption status at baseline, and physical activity level at baseline, and change in physical activity level in addition to variables in the table.

We considered various confounders in the analyses presented in Tables 2 and 3. Vitamin D supplement use and dose were not considered, as they do not qualify as confounders. A repeat of the analyses presented in Tables 2 and 3 with further consideration of supplement use and dose revealed very similar estimates for the associations of baseline $25(\mathrm{OH}) \mathrm{D}$ concentrations and temporal changes in $25(\mathrm{OH}) \mathrm{D}$ concentrations with the risk for elevated CRP concentrations at follow-up.

\section{Discussion}

We revealed that higher serum 25(OH)D concentrations at baseline were associated with a reduced risk for elevated CRP concentrations at follow-up among overweight and obese participants, and that temporal increases in serum $25(\mathrm{OH}) \mathrm{D}$ concentrations were paralleled with a reduction in the risk for elevated CRP concentrations among obese participants. No statistically significant associations of 25(OH)D with risk for elevated CRP were observed for underweight and normal weight participants. To the best of our knowledge, this is the first study that shows that changes in the risk for elevated CRP in response to temporal changes in $25(\mathrm{OH}) \mathrm{D}$ concentration differ by body weight.

Several observational studies, though not consistently, reported inverse associations of serum 25(OH)D concentrations with CRP concentrations [13-15,31,32]. Amer and Qayyum [14] observed the inverse association between $25(\mathrm{OH}) \mathrm{D}$ and CRP concentrations to exist for individuals with serum $25(\mathrm{OH}) \mathrm{D}$ concentrations $\leq 52.5 \mathrm{nmol} / \mathrm{L}$ but not for those with higher $25(\mathrm{OH}) \mathrm{D}$ concentrations. As individuals with excess body weight, on average, have lower serum $25(\mathrm{OH}) \mathrm{D}$ concentrations [33], one may speculate that the subgroup with serum $25(\mathrm{OH}) \mathrm{D}$ concentrations $\leq 52.5 \mathrm{nmol} / \mathrm{L}$ in the analyses by Amer and Qayyum [14] included relatively more individuals with excess body weight. One may further speculate that the revelation of the present study that the association between 25(OH)D and CRP exists for obese subjects and not for normal weight individuals, explains why the inverse association was shown for the subgroup with serum $25(\mathrm{OH}) \mathrm{D}$ concentrations $\leq 52.5 \mathrm{nmol} / \mathrm{L}$ and not for the subgroup with $25(\mathrm{OH}) \mathrm{D}>52.5 \mathrm{nmol} / \mathrm{L}$. In addition, Bellia et al. [13] had shown this inverse association of $25(\mathrm{OH}) \mathrm{D}$ with CRP to exist for obese subjects in a cross sectional study. The conclusion arising from the meta-analysis of vitamin D supplementation trials among overweight and obese individuals by Jamka et al. [23] seems to contradict the findings of these observational studies and of the present study that temporal increases in $25(\mathrm{OH}) \mathrm{D}$ concentrations are paralleled by decreases in CRP among obese subjects. Jamka et al. [23] had observed a reduction in CRP associated with supplementation but this was not statistically significant. One may speculate that this is attributable to 
sample size and statistical power as the analysis by Jamka et al. [23] were based on observations of 1955 subjects from 13 RCTs, whereas the present analyses included observations of 6755 participants. However, various other differences between the studies exist that may explain the differences in findings. The most prominent difference is that we analyzed changes in $25(\mathrm{OH}) \mathrm{D}$ concentrations which is an objective measure not affected by compliance to supplementation regimens, and includes the contribution of vitamin $\mathrm{D}$ from sunlight and diet. The conclusions arising from the meta analyses by Chen et al. [24] seems consistent with those of the present study, despite the fact that RCTs considered in Chen et al. [24] mostly consisted of patients with inflammatory complications and our analyses were based on a community sample of volunteers participating in a preventive health program. The present study herewith illustrates that the conclusions arising from RCTs in selected patients groups are also applicable to the population at large and those with obesity in particular.

Heaney et al. [34] showed that associations of $25(\mathrm{OH}) \mathrm{D}$ concentrations with insulin resistance and blood pressure exists but only for the range of approximately 40 to $90 \mathrm{nmol} / \mathrm{L}$ of 25(OH)D. No associations were found below and above these response thresholds. The response thresholds for the association of $25(\mathrm{OH}) \mathrm{D}$ with inflammation and CRP concentrations have yet to be investigated and reported. These thresholds are likely distinct from those for insulin resistance and blood pressure, given the conclusion of a recent review of the literature that vitamin $\mathrm{D}$ effects different health conditions at distinct serum 25(OH)D concentrations [35]. In the absence of knowledge of these thresholds, one should be cautious in the application of linear regression which assumes a linear relationship between the exposure $(25(\mathrm{OH}) \mathrm{D})$ and the outcome $(\mathrm{CRP})$ to the full range of the exposure $(25(\mathrm{OH}) \mathrm{D})$. This concern was mitigated in the present study by examining the risk for elevated CRP concentrations and employing established thresholds for CRP [27]. These thresholds allowed us to contrast CRP concentrations associated with low CVD-risk $(<1 \mathrm{mg} / \mathrm{L})$ with CRP concentrations associated with elevated CVD risk (average CVD-risk ( 1 to $<3 \mathrm{mg} / \mathrm{L})$ and high CVD-risk ( $\geq 3 \mathrm{mg} / \mathrm{L})$ combined) [27]. As such, the estimates for risk for elevated CRP may also be interpreted as risk for CVD [27]. It has been previously suggested that the responsible mechanism may involve the inhibitory effects of vitamin $D$ on synthesizing the primary stimulant of CRP production in the liver $[36,37]$ or the anti-inflammatory effect of vitamin D [38].

In addition to excess body weight, the present study confirmed that many of the conventional CVD risk factors including elevated LDL-cholesterol [1], increasing age [2], smoking [1,2], low level of physical activity [39,40] and overweight/obesity [2] were associated with an increased risk for elevated CRP. However, no statistically significant associations of blood pressure and alcohol consumption were observed. In addition, where male gender is an established risk factor for CVD [1], we observed a higher risk for elevated CRP concentrations among females.

The longitudinal design, large sample size and the wide range of serum $25(\mathrm{OH}) \mathrm{D}$ concentrations are strengths of the present study. As limitations we acknowledge that this study was conducted among volunteer participants of a preventive health program. These participants may not be representative of the general population. The preventive health program not only encourages supplementation with vitamin D, but rather healthy lifestyles in general. In this regard, we did report that physical active levels improved during follow-up. However, other lifestyle changes may also have occurred, though not recorded, and thus not allowing us to adjust for this in the analyses. Other limitations relate to inaccuracies of the vitamin $\mathrm{D}$ assay and the fact that vitamin $\mathrm{D}$ was routinely collected and subjected to the assay rather than batch-wise. The absence of information on serum parathyroid hormone concentrations as well as missing values for the confounding variables may have contributed to a partial adjustment for confounding. These limitations underline that caution is warranted in the interpretation and generalization of the present findings.

\section{Conclusions}

In conclusion, we revealed high serum $25(\mathrm{OH}) \mathrm{D}$ concentrations at baseline and prospective improvement in $25(\mathrm{OH}) \mathrm{D}$ concentrations decrease the risk for elevated serum CRP concentration in 
individuals with excess body weight but not in those with normal weight. In Canada, where $20 \%$ of adults are obese [41] and 39\% are vitamin D insufficient [42], adverse CRP concentrations are common, and CVD constitutes an enormous public health burden, promotion of adequate serum 25(OH)D concentrations along with healthy lifestyles that include healthy diets, physical activity, and abstaining from smoking may alleviate the public health burden associated with CVD.

Supplementary Materials: The following are available online at http://www.mdpi.com/2072-6643/8/11/696/s1, Table S1: Risk for elevated C-reactive protein concentration $(\geq 3 \mathrm{mg} / \mathrm{L})$ at follow-up by body weight status at baseline.

Acknowledgments: The authors wish to thank the Pure North S'Energy Foundation for allowing their data to be analyzed for the purpose of this article, and Peter Tran and Ken Fyle for the management and validation of the Foundation's data. PJV holds a Canada Research Chair in Population Health, an Alberta Research Chair in Nutrition and Disease Prevention, and an Alberta Innovates Health Scholarship. The funding for the Canada Research Chair is provided through the Canadian Institutes for Health Research to the University of Alberta. The Alberta Research Chair is awarded by the School of Public Health at the University of Alberta through a thematic research contract with the Pure North S'Energy Foundation. The Alberta Innovates Health Scholarship is funded by the Alberta provincial government through Alberta Innovates Health Solutions to the University of Alberta. MFM carries a postdoctoral fellowship supported by National Council for Scientific and Technological Development (CNPq), Brazil (contract grant number 249048/2013-2).

Author Contributions: M.F.M., T.-M.P. and P.J.V. conceived the study. T.-M.P., J.P.E. and P.J.V. decided on the analytic approach. T.M.P. and L.L.M. conducted the statistical analysis. S.S.B.S.M., L.L.M. and T.-M.P. conducted the literature review. S.S.B.S.M., L.L.M., T.-M.P., S.A.L. and P.J.V. wrote the manuscript. All authors reviewed and edited the manuscript.

Conflicts of Interest: The authors declare no conflict of interests.

\section{References}

1. Yousuf, O.; Mohanty, B.D.; Martin, S.S.; Joshi, P.H.; Blaha, M.J.; Nasir, K.; Blumenthal, R.S.; Budoff, M.J. High-sensitivity C-reactive protein and cardiovascular disease: A resolute belief or an elusive link. J. Am. Coll. Cardiol. 2013, 62, 397-408. [CrossRef] [PubMed]

2. Salazar, J.; Martínez, M.S.; Chávez, M.; Toledo, A.; Añez, R.; Torres, Y.; Apruzzese, V.; Silva, C.; Rojas, J.; Bermúdez, V. C-reactive protein: Clinical and epidemiological perspectives. Cardiol. Res. Pract. 2014, 2014, 1-10. [CrossRef] [PubMed]

3. Pepys, M.B.; Hirschfield, G.M. C-reactive protein: A critical update. J. Clin. Investig. 2003, 111, $1805-1812$. [CrossRef] [PubMed]

4. Dubinsky, M.C. Serologic and laboratory markers in prediction of the disease course in inflammatory bowel disease. World J. Gastroenterol. 2010, 16, 2604-2608. [CrossRef] [PubMed]

5. Hamer, M.; Bell, J.A.; Sabia, S.; Batty, G.D.; Kivimäki, M. Stability of metabolically healthy obesity over 8 years: The English Longitudinal Study of Ageing. Eur. J. Endocrinol. 2015, 173, 703-708. [CrossRef] [PubMed]

6. Bastien, M.; Poirier, P.; Lemieux, I.; Després, J.P. Overview of epidemiology and contribution of obesity to cardiovascular disease. Prog. Cardiovasc. Dis. 2014, 56, 369-381. [CrossRef] [PubMed]

7. McGown, C.; Birerdinc, A.; Younossi, Z.M. Adipose tissue as an endocrine organ. Clin. Liver Dis. 2014, 18, 41-58. [CrossRef] [PubMed]

8. McPherson, R.; Frohlich, J.; Fodor, G.; Genest, J. Canadian Cardiovascular Society position statement-recommendations for the diagnosis and treatment of dyslipidemia and prevention of cardiovascular disease. Can. J. Cardiol. 2006, 22, 913-927. [CrossRef]

9. Ridker, P.M. High-Sensitivity C-Reactive Protein: Potential Adjunct for Global Risk Assessment in the Primary Prevention of Cardiovascular Disease. Circulation 2001, 103, 1813-1818. [CrossRef] [PubMed]

10. Holick, M.F. Vitamin D deficiency. N. Engl. J. Med. 2007, 357, 266-281. [CrossRef] [PubMed]

11. Verstuyf, A.; Carmeliet, G.; Bouillon, R.; Mathieu, C. Vitamin D: A pleiotropic hormone. Kidney Int. 2010, 78, 140-145. [CrossRef] [PubMed]

12. Lindqvist, P.G.; Epstein, E.; Nielsen, K.; Landin-Olsson, M.; Ingvar, C.; Olsson, H. Avoidance of sun exposure as a risk factor for major causes of death: A competing risk analysis of the Melanoma in Southern Sweden cohort. J. Intern. Med. 2016, 280, 375-387. [CrossRef] [PubMed] 
13. Bellia, A.; Garcovich, C.; D’Adamo, M.; Lombardo, M.; Tesauro, M.; Donadel, G.; Gentileschi, P.; Lauro, D.; Federici, M.; Lauro, R.; et al. Serum 25-hydroxyvitamin D levels are inversely associated with systemic inflammation in severe obese subjects. Intern. Emerg. Med. 2013, 8, 33-40. [CrossRef] [PubMed]

14. Amer, M.; Qayyum, R. Relation between serum 25-hydroxyvitamin D and C-reactive protein in asymptomatic adults (from the continuous National Health and Nutrition Examination Survey 2001 to 2006). Am. J. Cardiol. 2012, 109, 226-230. [CrossRef] [PubMed]

15. Murr, C.; Pilz, S.; Grammer, T.B.; Kleber, M.E.; Meinitzer, A.; Boehm, B.O.; Marz, W.; Fuchs, D. Vitamin D deficiency parallels inflammation and immune activation, the Ludwigshafen Risk and Cardiovascular Health (LURIC) study. Clin. Chem. Lab. Med. 2012, 50, 2205-2212. [CrossRef] [PubMed]

16. Duggan, C.; de Dieu Tapsoba, J.; Mason, C.; Imayama, I.; Korde, L.; Wang, C.Y.; Tiernan, A. Effect of vitamin D3 supplementation in combination with weight loss on inflammatory biomarkers in postmenopausal women: A randomized controlled trial. Cancer Prev. Res. 2015, 8, 628-635. [CrossRef] [PubMed]

17. Liefaard, M.C.; Ligthart, S.; Vitezova, A.; Hofman, A.; Uitterlinden, A.G.; Kiefte-de Jong, J.C.; Franco, O.H.; Zillikens, M.C.; Dehghan, A. Vitamin D and C-Reactive Protein: A Mendelian Randomization Study. PLoS ONE 2015, 10, e0131740. [CrossRef] [PubMed]

18. Shah, S.; Wilson, D.M.; Bachrach, L.K. Large doses of vitamin D fail to increase 25 hydroxyvitamin D levels or to alter cardiovascular risk factors in obese adolescents: A pilot study. J. Adolesc. Health 2015, 57, 19-23. [CrossRef] [PubMed]

19. Chandler, P.D.; Scott, J.B.; Drake, B.F.; Ng, K.; Manson, J.E.; Rifai, N.; Chan, A.T.; Bennett, G.G.; Hollis, B.W.; Giovannucci, E.L.; et al. Impact of vitamin D supplementation on inflammatory markers in African Americans: Results of a four-arm, randomized, placebo-controlled trial. Cancer Prev. Res. 2014, 7, $218-225$. [CrossRef] [PubMed]

20. Witham, M.D.; Dove, F.J.; Khan, F.; Lang, C.C.; Belch, J.J.; Struthers, A.D. Effects of Vitamin D supplementation on markers of vascular function after myocardial infarction-A randomised controlled trial. Int. J. Cardoil. 2013, 167, 745-749. [CrossRef] [PubMed]

21. Jorde, R.; Sneve, M.; Torjesen, P.A.; Figenschau, Y.; Gøransson, L.G.; Omdal, R. No effect of supplementation with cholecalciferol on cytokines and markers of inflammation in overweight and obese subjects. Cytokine 2010, 50, 175-180. [CrossRef] [PubMed]

22. Pittas, A.G.; Harris, S.S.; Stark, P.C.; Dawson-Hughes, B. The effects of calcium and vitamin D supplementation on blood glucose and markers of inflammation in nondiabetic adults. Diabetes Care 2007, 30, 980-986. [CrossRef] [PubMed]

23. Jamka, M.; Woźniewicz, M.; Walkowiak, J.; Bogdański, P.; Jeszka, J.; Stelmach-Mardas, M. The effect of vitamin D supplementation on selected inflammatory biomarkers in obese and overweight subjects: A systematic review with meta-analysis. Eur. J. Nutr. 2015, 55, 2163-2175. [CrossRef] [PubMed]

24. Chen, N.; Wan, Z.; Han, S.F.; Li, B.Y.; Zhang, Z.L.; Qin, L.Q. Effect of vitamin D supplementation on the level of circulating high-sensitivity C-reactive protein: A meta-analysis of randomized controlled trials. Nutrients 2014, 6, 2206-2216. [CrossRef] [PubMed]

25. Pham, T.M.; Ekwaru, J.P.; Setayeshgar, S.; Veugelers, P.J. The Effect of Changing Serum 25-Hydroxyvitamin D Concentrations on Metabolic Syndrome: A Longitudinal Analysis of Participants of a Preventive Health Program. Nutrients 2015, 7, 7271-7284. [CrossRef] [PubMed]

26. Veugelers, P.J.; Pham, T.M.; Ekwaru, J.P. Optimal Vitamin D Supplementation Doses that Minimize the Risk for Both Low and High Serum 25-Hydroxyvitamin D Concentrations in the General Population. Nutrients 2015, 7, 10189-10208. [CrossRef] [PubMed]

27. Pearson, T.A. Markers of Inflammation and Cardiovascular Disease: Application to Clinical and Public Health Practice: A Statement for Healthcare Professionals from the Centers for Disease Control and Prevention and the American Heart Association. Circulation 2003, 107, 499-511. [CrossRef] [PubMed]

28. Helal, I.; Zerelli, L.; Krid, M.; ElYounsi, F.; Maiz, H.B.; Zouari, B.; Adelmoula, J.; Kheder, A. Comparison of C-reactive protein and high-sensitivity C-reactive protein levels in patients on hemodialysis. Saudi J. Kidney Diseases Transplant. 2012, 23, 477.

29. Lau, D.C.W.; Milan, G.; Pearson, G.J. New Canadian Guidelines for the Diagnosis and Management of Dyslipidemia-2009 Update. Available online: http:/ / www.canadianhealthcarenetwork.ca/files/2010/02/ Dyslipidemia_Guidelines_Feb2010.pdf (accessed on 20 August 2016). 
30. National Institute of Health. Clinical Guidelines on the Identification, Evaluatiuon, and Treatment of Overweight and Obesity in Adults. Available online: http://www.nhlbi.nih.gov/files/docs/guidelines/ob_ gdlns.pdf (accessed on 12 July 1998).

31. Akin, F.; Ayça, B.; Köse, N.; Duran, M.; Sari, M.; Uysal, O.K.; Karakukcu, C.; Arinc, H.; Covic, A.; Goldsmith, D.; et al. Serum vitamin D levels are independently associated with severity of coronary artery disease. J. Investig. Med. 2012, 60, 869-873. [CrossRef] [PubMed]

32. Michos, E.D.; Streeten, E.A.; Ryan, K.A.; Rampersaud, E.; Peyser, P.A.; Bielak, L.F.; Shuldiner, A.R.; Mitchell, B.D.; Post, W. Serum 25-hydroxyvitamin d levels are not associated with subclinical vascular disease or C-reactive protein in the old order amish. Calcif. Tissue Int. 2009, 84, 195-202. [CrossRef] [PubMed]

33. Ekwaru, J.P.; Zwicker, J.D.; Holick, M.F.; Giovannucci, E.; Veugelers, P.J. The importance of body weight for the dose response relationship of oral vitamin D supplementation and serum 25-hydroxyvitamin D in healthy volunteers. PLOS ONE 2014, 9, e111265. [CrossRef] [PubMed]

34. Heaney, R.P. Guidelines for optimizing design and analysis of clinical studies of nutrient effects. Nutr. Rev. 2014, 72, 48-54. [CrossRef] [PubMed]

35. Spedding, S.; Vanlint, S.; Morris, H.; Scragg, R. Does vitamin D sufficiency equate to a single serum 25-hydroxyvitamin D level or are different levels required for non-skeletal diseases. Nutrients 2013, 5, 5127-5139. [CrossRef] [PubMed]

36. Zhang, Y.; Leung, D.Y.; Richers, B.N.; Liu, Y.; Remigio, L.K.; Riches, D.W.; Goleva, E. Vitamin D inhibits monocyte/macrophage proinflammatory cytokine production by targeting MAPK phosphatase-1. J. Immunol. 2012, 188, 2127-2135. [CrossRef] [PubMed]

37. Dickie, L.J.; Church, L.D.; Coulthard, L.R.; Mathews, R.J.; Emery, P.; McDermott, M.F. Vitamin D3 down-regulates intracellular Toll-like receptor 9 expression and Toll-like receptor 9-induced IL-6 production in human monocytes. Rheumatology 2010, 49, 1466-1471. [CrossRef] [PubMed]

38. Zittermann, A.; Schleithoff, S.S.; Koerfer, R. Putting cardiovascular disease and vitamin D insufficiency into perspective. Br. J. Nutr. 2005, 94, 483. [CrossRef] [PubMed]

39. Mora, S.; Cook, N.; Buring, J.E.; Ridker, P.M.; Lee, I.M. Physical activity and reduced risk of cardiovascular events: Potential mediating mechanisms. Circulation 2007, 116, 2110-2118. [CrossRef] [PubMed]

40. Myers, J. Exercise and Cardiovascular Health. Circulation 2003, 107, e2-e5. [CrossRef] [PubMed]

41. Statistics Canada. Overweight and Obese Adults (Self-Reported), 2014. Available online: http://www. statcan.gc.ca/pub/82-625-x/2015001/article/14185-eng.htm (accessed on 18 August 2016).

42. Statistics Canada. Vitamin D Levels of Canadians, 2012 to 2013. Available online: http:/ /www.statcan.gc. ca/pub/82-625-x/2014001/article/14125-eng.htm (accessed on 18 August 2016). 